\title{
The Relationship Between Public Expenditures and Foreign Trade Deficit: The Case of Turkey
}

\author{
Mustafa Gerceker, Ibrahim Ozmen and Mehmet Mucuk
}

Selcuk University

\begin{abstract}
Governments have to spend to meet social needs and intervene in economic life. Although these expenditures contribute positively to economic growth through the multiplier mechanism, they may lead to the foreign trade deficit. The foreign trade deficit is an important problem, especially for developing countries. Because interest rates must be raised to bring foreign savings to the country to finance the deficit. As a result of the increase in interest rates, investments will decrease. Besides, rising interest rates will negatively affect other components of aggregate demand and disrupt resource allocation. Therefore, the state should prefer domestic products more. Otherwise, because of the foreign trade deficit problem, the government attempts to cool the economy. This situation will cause a slowdown in the economic development process. This study aims to analyze the causal relationship between public expenditures and foreign trade deficit for the Turkish economy. The foreign trade deficit is among the main problems of Turkey's economy.
\end{abstract}

Keywords: public expenditures; trade deficit; causality; twin deficits; Turkish economy

\section{Introduction}

Globalization has changed the picture of the world economy by increasing the movements of cross-border trade, capital flow, and production factors (Akram et al., 2011: 291). However, due to social, economic, and political factors, the effects of globalization vary from country to country and from region to region. It is seen that underdeveloped countries with small production amounts and weak production techniques become more dependent on other countries in the process of globalization (Afzal, 2007: 732). There are four different types of foreign dependence on financial sources. These are commodity export dependence, country export dependence, debt dependence, and dependence on foreign investment (Rubinson, 1977: 6-7). As commodity dependency increases, the export-import balance gradually deteriorates and the external deficit 
problem deepens. Among the reasons for the problem of the external deficit are the variables such as interest rate, inflation, exchange rate, economic growth, and domestic demand. One of the main components of domestic demand is the public sector.

In today's conditions, governments do not only spend to meet social needs but also to regulate economic activities (Turk, 2001: 11). Hence, according to the Keynesian approach, public expenditures at the underemployment level contribute to the increase in national income through the multiplier mechanism. However, for the expected effect to fully transpire, the public must demand domestic products. Otherwise, the multiplier effect is not only reflected abroad but also it affects the external balance negatively (Guran, 1996: 135-136). Therefore, in a significant number of countries with different levels of development, governments prioritize domestic products when purchasing.

The external deficit problem is also one of the fundamental economic problems in Turkey, which is a developing country. In this context, it is emphasized that the public sector should prefer domestic products both to support domestic production and to alleviate the problem of external deficits. This is clearly stated in the development plans. For example, in the 10th Development Plan, it is stated that public procurement does not provide sufficient contribution to technology transfer or development of the industry. Additionally, it is stated that public procurement is used extensively as a policy tool to support domestic production and technology development in developed countries. Therefore, the purpose is to carry out public procurement to encourage innovation, localization, technology transfer, and innovative entrepreneurship (Republic of Turkey Ministry of Development, 2015: 1). Because the increase in external deficits creates a financing problem.

To finance external deficits, foreign savings should be brought against high-interest rates. Increasing interest rates may lead to a decrease in investments, deterioration of resource allocation, economic contraction and budget deficits. And all this brings about economic instability (Kazgan, 2005: 14). This study analyzes whether public procurement has an impact on the external deficit considering the data about the Turkish economy for the period between 19872017 using unit root tests and causality tests.

The rest of the paper is organized as follows. Section 2 presents a brief literature review on public expenditures and trade deficit. Section 3 explains the data, methodology, and empirical findings. Finally section 4 concludes the paper with policy suggestions.

\section{Literature Review}

There are many studies in the empirical literature that test the twin deficits hypothesis by using the budget deficit and foreign trade deficit variables. However, there are only a limited number of studies that conduct econometric analysis taking into account the variables of public expenditure and foreign trade deficit. In this context, the literature summary for the studies that address the relationship between public expenditure and foreign trade deficit in Turkey are presented in Table 1. 
Table 1. Literature Survey

\begin{tabular}{|c|c|c|c|c|}
\hline Author(s) & Countries & Period & Methodology & Results \\
\hline $\begin{array}{l}\text { Kayhan et al. } \\
(2013)\end{array}$ & Turkey & $\begin{array}{l}\text { 1987Q1- } \\
\text { 2011Q3 }\end{array}$ & $\begin{array}{l}\text { Hacker and } \\
\text { Hatemi-J(2006) } \\
\text { Causality Test, } \\
\text { Frequency Domain } \\
\text { Causality Test }\end{array}$ & $\begin{array}{l}\text { There is bi-directional causality } \\
\text { between public expenditures and } \\
\text { foreign trade deficits. }\end{array}$ \\
\hline Adıgüzel (2014) & Turkey & $\begin{array}{l}\text { 1982Q1- } \\
\text { 2010Q3 }\end{array}$ & $\begin{array}{lr}\text { Kejriwal } & (2008) \\
\text { and } & \text { Kejriwal- } \\
\text { Perron } & (2009) \\
\text { Cointegration Test }\end{array}$ & $\begin{array}{l}\text { There is cointegration between } \\
\text { variables in the long run. } \\
\text { According to results, there is a } \\
\text { structural break in 2000Q1. } \\
\text { While public expenditures had } \\
\text { an impact on foreign trade } \\
\text { deficits in the } 1990 \text { s, the effect } \\
\text { decreased after the year } 2000 \text {. }\end{array}$ \\
\hline $\begin{array}{l}\text { Kayhan et } \\
\text { al.(2016) }\end{array}$ & Turkey & $1987-2014$ & $\begin{array}{l}\text { Hatemi-J - Roca } \\
\text { (2014) Asymmetric } \\
\text { Causality Test, } \\
\text { Frequency Domain } \\
\text { Causality Test }\end{array}$ & $\begin{array}{l}\text { There is bi-directional causality } \\
\text { between public expenditures and } \\
\text { foreign trade deficits. } \\
\text { Asymmetric causality analysis } \\
\text { results indicate that an increase } \\
\text { in public expenditures reduces } \\
\text { the trade deficit. }\end{array}$ \\
\hline $\begin{array}{l}\text { Özpençe and } \\
\text { Ergen (2017) }\end{array}$ & Turkey & $1965-2015$ & $\begin{array}{l}\text { Gregory-Hansen } \\
(1996) \\
\text { Cointegration Test, } \\
\text { FMOLS Estimation }\end{array}$ & $\begin{array}{l}\text { There is cointegration between } \\
\text { variables in the long run. } \\
\text { FMOLS estimation results } \\
\text { indicate that an increase in } \\
\text { public expenditures increases } \\
\text { foreign trade deficits. }\end{array}$ \\
\hline
\end{tabular}

In contrast to the studies in Table 1, Cavallo (2005) tested the effect of public consumption expenditures on the current account balance for the US economy using impulse-response analysis based on data for the period of 1948-2000. Findings showed that public final goods expenditures significantly disrupted the current account balance.

\section{Data, Methodology and Findings}

Variables and sources used in the analysis to determine the causal relationship between the foreign trade deficit in public expenditures in Turkey are listed in Table 2.

Table 2. Data and Sources

\begin{tabular}{|l|c|c|c|}
\hline Data & Abbreviation & Sources & Sample \\
\hline Foreign Trade Deficit $^{\mathrm{a}}$ & $\mathrm{Td}$ & WDI & $1987-2017$ \\
\hline Government Expenditure $^{\mathrm{b}}$ & $\mathrm{Ex}$ & Turkish Revenue Administration & $1987-2017$ \\
\hline
\end{tabular}


In the analysis, total current expenditures and investment expenditures excluding transfers and personnel expenses were considered as public expenditures. Total public expenditures were not considered because they were more likely to have a direct impact on the foreign trade balance. To determine the relationship between these variables, Hacker and Hatemi-J (2006) bootstrap Toda and Yamamoto causality test (BTY) and Fourier Toda and Yamamoto causality test (FTY) developed by Nazlioglu et al. (2016) were used. Ng and Perron (2001) first-generation unit root tests and ADF-based DF-GLS unit root test developed by Elliott, Rothenberg, and Stock (1996) were used for BTY. On the other hand, Fourier type Fourier Augmented Dickey-Fuller (FADF) (Enders and Lee, 2012) and Fourier Kwiatkowski-Phillips-Schmidt-Shin (FKPSS) (Becker et al., 2006) unit root tests were performed for FTY.

\section{Unit Root Tests}

We investigate firstly whether shocks to a series are temporary or permanent. For this purpose $\mathrm{Ng}$ and Perron (2001) unit root tests and ADF-based DF-GLS unit root tests developed by Elliott, Rothenberg, and Stock (1996), which can provide strong results even for small samples, were preferred. In Ng-Perron unit root tests (Mza, Mzt, MSB, and MST) and DF-GLS test, the $\mathrm{H} 0$ hypothesis (series includes unit root) was tested against the H1 hypothesis (series is stationary).

On the other hand, if time series show a linear or nonlinear tendency, Fourier-type unit root tests can be used for stationarity testing (Becker et al., 2006: 381-382; Yalcinkaya, 2019: 40). Within this framework, Fourier type Fourier Augmented Dickey-Fuller (FADF) (Enders and Lee, 2012) and Fourier Kwiatkowski-Phillips-Schmidt-Shin (FKPSS) (Becker et al., 2006) unit root tests were performed. If the value calculated in FKPSS unit root test is less than the critical value, the $\mathrm{HO}$ hypothesis cannot be rejected and it is accepted that there is no unit root; if the absolute value of the value calculated in the FADF test is greater than the critical value, the HO hypothesis is rejected and the alternative hypothesis, which suggests there is no unit root, is accepted.

The findings of the first generation unit root tests are presented in Table 3.

Table 3. Results of First Generation Unit Root Tests

\begin{tabular}{|c|c|c|c|c|c|}
\hline Variable & DF-GLS & Mza & $\mathbf{M z}_{\mathbf{t}}$ & MSB & MST \\
\hline $\mathrm{Td}$ & $-2.68^{*}$ & -9.52 & -2.14 & 0.22 & 2.72 \\
\hline$\Delta \mathrm{Td}$ & $-6.86^{*}$ & $-13.50^{*}$ & $-2.59^{*}$ & 0.18 & $0.59^{*}$ \\
\hline$\Delta \Delta \mathrm{Td}$ & $-8.68^{*}$ & $-44.15^{*}$ & $-4.68^{*}$ & $0.10^{*}$ & 10.85 \\
\hline $\operatorname{lnEx}$ & -0.49 & -1.83 & -0.75 & 0.41 & 6.90 \\
\hline$\Delta \operatorname{lnEx}$ & -1.62 & -3.53 & -1.21 & 0.34 & $2.05^{* *}$ \\
\hline$\Delta \Delta \operatorname{lnEx}$ & $-5.12^{*}$ & $-13.04 * *$ & $-2.50 * *$ & $0.19 * *$ & 1.78 \\
\hline$\% 1$ & -2.65 & -13.8 & -2.58 & 0.17 & 3.17 \\
\hline
\end{tabular}

Notes: The optimal lag(s) (3) were determined by the Schwarz information criterion for DF- GLS and Ng-Perron tests. *, and ** denote 1 , and 5, percent level of statistical significance, respectively. 
According to Ng-Perron unit root test results, it is seen that the variable of $\mathrm{Td}$ is I (2). According to DF-GLS results, although Td is I (0), Td is the second difference stationary when all $\mathrm{Ng}$ Perron tests are considered. On the other hand, according to all tests, the variable lnEx is I (2) for the significance level of $5 \%$.

The results of the Fourier unit root test are presented in Table 4.

Table 4. Results of Fourier Unit Root Tests

\begin{tabular}{|c|c|c|c|c|c|c|c|c|c|c|}
\hline Series & \multicolumn{5}{|c|}{ FADF (Enders ve Lee, 2012) } & \multicolumn{5}{|c|}{ FKPSS (Beckers et al., 2006) } \\
\hline \multicolumn{11}{|c|}{ Constant } \\
\hline Level & Stat. & $\mathbf{L}$ & $\mathbf{K}$ & $\% 5$ & $\% 10$ & Stat. & $\mathbf{L}$ & $\mathbf{K}$ & $\% 5$ & $\% 10$ \\
\hline $\mathrm{Td}$ & -3.48 & 3 & 1 & -3.81 & -3.49 & $0.11^{* *}$ & 0 & 1 & 0.17 & 0.13 \\
\hline $\ln E x$ & -1.19 & 3 & 1 & -3.81 & -3.49 & 0.96 & 0 & 1 & 0.17 & 0.13 \\
\hline \multicolumn{11}{|c|}{ First Difference } \\
\hline$\Delta \mathrm{Td}$ & $-6.92^{* *}$ & 1 & 5 & -2.93 & -2.60 & $0.02^{* *}$ & 0 & 5 & 0.46 & 0.35 \\
\hline$\Delta \ln E x$ & $-3.63^{* * * *}$ & 1 & 1 & -3.81 & -3.49 & $0.06^{* *}$ & 0 & 1 & 0.17 & 0.13 \\
\hline
\end{tabular}

Notes: The critical values of each test were compiled from the table values in the related articles. L: lag number, K: Fourier number. Maximum $K$ is (5). Maximum L is (3). Optimal $K$ and $L$ determined by the Akaike information criterion. $* *$, and $* * *$ denote 5 , and 10, percent level of statistical significance, respectively.

According to the results of both unit root tests in Table 4, hypotheses that the series do not contain a unit root at the level could not be rejected. At the first difference, the Td and $\operatorname{lnEx}$ variables do not contain a unit root. In other words, the series are I (1).

\section{Causailty Tests}

Finally in this study, the BTY causality test developed by Hacker and Hatemi-J (2006) and the FTY causality test developed by Nazlioglu et al. (2016) was preferred. Both methods are based on the causality test developed by Toda-Yamamoto (TY) (1995). The TY test overcomes some of the disadvantages of the standard Granger (1969) causality test. Because the standard Granger causality test requires unit root and cointegration tests to be conducted as well. In contrast, the TY test is resistant to the unit root and cointegration characteristics of the VAR system (Nazlioglu et al., 2016: 172).

Hacker and Hatemi-J (2006) developed the Modified Wald test, stating that asymptotic distribution might be a weak approximation for small samples. In this context, they added the distributions produced by the bootstrap technique to the features of the TY test (Hacker and Hatemi-J, 2006: 1499). The FTY test also takes into account possible structural breaks in the series. Fourier approach was developed with the consideration that these fractures may be sudden/certain or smooth transitioning, it does not require prior knowledge of the numbers, 
dates, and forms of the fractures. The FTY test detects structural shifts as a gradual/soft process using a small number of low-frequency components (Nazlioglu et al. 2016: 172)

The causality findings for the BTY and FTY tests are presented in Table 5 and Table 6.

Table 5. Results of BTY Causality Test

\begin{tabular}{|l|c|c|c|c|}
\hline \multirow{2}{*}{ Hypothesis } & & \multicolumn{3}{|c|}{ Bootstrap critical values } \\
\cline { 2 - 5 } & MWald Stat. & $\mathbf{\% 1}$ & $\mathbf{\% 5}$ & $\mathbf{\% 1 0}$ \\
\hline $\ln E x \neq>\mathrm{Td}$ & 3.290 & 13.780 & 7.831 & 5.477 \\
\hline $\mathrm{Td} \neq>\ln E x$ & 0.211 & 15.125 & 7.469 & 5.267 \\
\hline
\end{tabular}

Notes: The maximum lag based on the VAR estimate is 1 according to the AIC, HQ and SCH information criteria. The maximum lag of the series is 2. So; $p+d$ is 3. Bootstrap p-values are based on 1000 replications. Mwald test statistic shows the test statistic obtained from the equation in Hacker and Hatemi-J (2006). The null hypothesis (X $\neq>Y$ ) implies that $X$ does not Granger-cause $Y$.

Table 6. Results of FTY Causality Test

\begin{tabular}{|c|c|c|c|c|c|c|c|c|c|c|}
\hline \multirow[b]{2}{*}{ Tests } & \multicolumn{5}{|c|}{$\ln \mathrm{Ex} \neq>\mathrm{Td}$} & \multicolumn{5}{|c|}{$T d \not>\ln E x$} \\
\hline & $\begin{array}{c}\mathbf{F} \\
\text { stat. }\end{array}$ & $\mathbf{P}$ & $\mathbf{F}$ & $\begin{array}{c}\text { bootstrap } \\
\text { p-value }\end{array}$ & Desicion & $\begin{array}{c}\mathbf{F} \\
\text { stat. }\end{array}$ & $\mathbf{P}$ & $\mathbf{F}$ & $\begin{array}{c}\text { bootstrap } \\
\text { p-value }\end{array}$ & Desicion \\
\hline $\begin{array}{l}\text { Single } \\
\text { frequency } \\
\text { FTY }\end{array}$ & 0.434 & 2 & 1 & 0.925 & $\begin{array}{c}\mathrm{H}_{0} \\
\text { Accepted }\end{array}$ & 2.864 & 2 & 1 & 0.422 & $\mathrm{H}_{0}$ Accepted \\
\hline
\end{tabular}

Notes: Maximum lags number $(p)$ and fourier number $(f)$ are determined by Akaike information criterion. Where $p+$ $d$ is 2 . Bootstrap p-values are based on 1000 replications. $\neq>$ denotes the null hypothesis of Granger non-causality.

According to the results of BTY and FTY in Table 5 and Table 6, there is no statistically significant relationship between public expenditures and the foreign trade deficit.

\section{Conclusion}

The globalization process has brought about commercial liberalization worldwide. This caused foreign trade deficits to deepen, especially in a significant number of underdeveloped countries. Foreign trade deficits create serious financing problems. One of the main reasons for these deficits is domestic demand. Public expenditures are also among the main components of domestic demand. On one hand, the increase in public expenditures causes economic growth with a multiplier mechanism and on the other hand, it stimulates import demand and negatively affects net exports. There are different findings in the literature about whether public expenditures have an impact on foreign trade deficits. In this study, using the data for the period of 1987-2017 regarding Turkey's economy, the relationship between public expenditure and foreign trade deficit was examined using bootstrap and Fourier Toda and Yamamoto causality tests. According to the results, there is no causal relationship between public expenditures (excluding transfers and personnel expenses) and foreign trade deficit. 


\section{References}

[1] Akram, M., Muhammad, A.F., Muhammad K.B.D and Iqra A. (2011). Globalization and its Impacts on the World Economic Development. International Journal of Business and Social Science, 2(23), 291-297.

[2] Afzal, M.(2007). The Impact of Globalisation on Economic Growth of Pakistan. The Pakistan Development Review, 46(4 Part II), 723-734.

[3] Rubinson, R. (1977). Dependence, Government Revenue, and Economic Growth, 1955-1970. Studies in Comparative International Development, 12(2), 3-28.

[4] Turk, İ. (2001). Maliye Politikası Amaçlar - Araçlar ve Çağdaş Bütçe Teorileri. Ankara: Turhan Kitabevi.

[5] Güran, N. (1996). Makro Ekonomik Analiz. İzmir: Karınca Matbaacılık.

[6] Republic of Turkey Ministry of Development, (2015). Kamu Alımları Yoluyla Teknoloji Geliştirme ve Yerli Üretim Programı Eylem Planı. Ankara: Republic of Turkey Ministry of Development,

[7] Kazgan, G. (2005). Türkiye Ekonomisinde Krizler (1929-2001) “Ekonomi Politik” Açısından Bir İnceleme. İstanbul: İstanbul Bilgi Üniversitesi Yayınları.

[8] Kayhan, S., Bayat, T., and Yüzbaşı, B. (2013). Government expenditures and trade deficits in Turkey: Time domain and frequency domain analyses. Economic Modelling, 35, 153-158.

[9] Adigüzel, U. (2014). Türkiye'de Kamu Harcamalari diş ticaret açiklari üzerinde etkili mi?. Akademik Araştırmalar ve Çalışmalar Dergisi (AKAD), 6(10).

[10] Kayhan, S., Adıgüzel, U., and Sökmen, F. Ş. (2016, October). Kamu Harcamaları-Dış Ticaret Açı̆̆ı İlişkisi: Birbirlerini Aynı Yönde mi Etkiler? Türkiye Örneği. In ICPESS (International Congress on Politic, Economic and Social Studies) (No. 1).

[11] Ozpençe, A. I.,and Ergen, E. (2017). Kamu Harcamalari ve Diş Ticaret Açiklari İlişkisi: Türkiye Örneği. Kastamonu Üniversitesi İktisadi ve İdari Bilimler Fakültesi Dergisi, 19(4), 134145.

[12] Cavallo, M. (2005). Government Consumption Expenditures and the Current Account. Federal Reserve Bank of San Francisco, Woriking Paper Series, WP No: 2005-03.

[13] Hacker, R. Scott and Hatemi-J, Abdulnasser (2006), Tests for causality between integrated variables using asymptotic and bootstrap distributions: theory and application, Applied Economics, 38 (13), 1489-1500.

[14] Nazlıŏlu S., N. Görmüş, A. and Soytaş, U. (2016). Oil prices and real estate investment trusts (REITs): Gradual-shift causality and volatility transmission analysis, Energy Economics, 60, 168-175.

[15] Ng, S. and Perron, P. (2001). Lag Length Selection and Construction of Unit Root Tests with Good Size and Power, Econometrica, 69(6), 1519-1554.

[16] Elliott, G., Rothenberg, T., Stock, J. H. (1996). Efficient Tests for an Autoregressive Unit Root. Econometrica, 64, 813-836. 
ical|atyme

$2^{\text {nd }}$ International Conference on Advanced Research in BUSINESS, MANAGEMENT \& ECONOMICS
MUNICH, GERMANY

6 - 8 DECEMBER, 2019

[17] Enders, W. and Lee, J. (2012), The flexible Fourier form and Dickey-Fuller type unit root test, Economics Letters, 117, 196-199.

[18] Becker, R. , Enders, W. and Lee J. (2006). A Stationary Test in the Presence of an Unknown Number of Smooth Breaks, Journal of Time Series Analysis, 27(3), 381-409

[19] Yalcınkaya, Ö. (2019). Türkiye Ekonomisinde Dış Borçların Sürdürülebilirliğinin Analizi: Doğrusal ve Doğrusal Olmayan Birim Kök Testlerinden Kanıtlar (1970-2018). Maliye Dergisi, $176,27-51$.

[20] Toda, H. Y. and Yamamoto, T. (1995), Statistical inference in vector autoregressions with possibly integrated processes, Journal of Econometrics, 66, 225-250.

[21] Granger, C. W. (1969), Investigating Causal Relations by Econometric Models and CrossSpectral Methods. Econometric 37, 424-438.

www.icabme.org 